\title{
Transmission of Hepatitis B virus (HBV) minor variants in children born to HBV/HIV co-infected mothers
}

Woottichai Khamduang*1,2, Catherine Gaudy-Graffin², Alain Moreau², Nicole Ngo-Giang-Huong 3 , Gonzague Jourdain ${ }^{3}$, Marc Lallemant ${ }^{3}$, Surachai Pipatnakulchai ${ }^{4}$, Chaiwat Putiyanun ${ }^{4}$, Sura Kunkongkapan ${ }^{4}$, Pornpun Wannarit ${ }^{4}$, Surat Sirinontakan ${ }^{4}$, Wanna Ardong ${ }^{4}$, Wasna Sirirungsi ${ }^{1}$ and Alain Goudeau ${ }^{2}$

Address: ${ }^{1}$ Faculty of Associated Medical Sciences, Chiang Mai University, Chiang Mai, Thailand, 2INSERM U966, CHU Tours, Faculté de Médecine, Université François-Rabelais, Tours, France, ${ }^{3}$ Institut de Recherche pour le Developpement UMI 174/Programs for HIV Prevention and Treatment (PHPT), Chiang Mai, Thailand and ${ }^{4}$ Ministry of Public Health, Nonthaburi, Thailand

* Corresponding author

from Fifth Dominique Dormont International Conference. Mother-to-child transmitted viral diseases: from transmission to children care Paris, France. 26-28 March 2009

Published: 22 July 2009

Retrovirology 2009, 6(Suppl I):O9 doi:10.1/86/1742-4690-6-SI-O9

This abstract is available from: http://www.retrovirology.com/content/6/SI/O9

(c) 2009 Khamduang et al; licensee BioMed Central Ltd.

\section{Background}

Since 1992, the Ministry of Public Health has integrated newborns HBV vaccination into the national expanded program on immunization. However, some children acquire HBV infection despite immunization.

\section{Objective}

To characterize HBV vaccine escape mutants in infants born to HBV/HIV-1 co-infected mothers.

\section{Methods}

Of 1433 HIV-infected women participating in the perinatal HIV prevention trial (PHPT-1), 107 were HBsAg positive. Five transmitted HBV to their children despite HBV vaccination in their children were documented. Blood samples collected from mothers during pregnancy and children at 4 and 6 months of age were analyzed by direct PCR sequencing of the $S$ gene ("a" determinant region and flanking regions). HBV variants were sequenced after cloning of PCR products into pGEM-T ${ }^{\circledR}$ easy vector $(20-25$ clones by samples). Sequencing was performed using the BigDye Terminator V.3.1 sequencing kit, Applied Biosystem. Sequence alignments were performed using Bioedit software. HBV serotype was inferred from results at codons $122,127,160,177$ and 178 of the $S$ gene.

\section{Results}

Complete samples series were available for 3 motherchild pairs, all infected by HBV genotype C. Infant virus direct sequencing showed no known vaccine escape mutation. However, direct sequencing identified the sK122R mutation in 2 infants but not in their mother. The predicted dominant HBV serotype in the 2 mothers was adra+, while it was ayr in the 2 children at 4 months of age. Although sK122R was not detected by direct sequencing, further analysis of maternal clones showed that the 2 mothers harbored this minor variant at very low frequency ( 1 of 65 clones and 2 of 67 clones, respectively). Analysis of children HBV clones showed an increase of ayr variants from 4 months to 6 months.

\section{Conclusion}

Although the impact of the sK122R mutation on HBV vaccine escape is unknown, this study suggests that HBV minor maternal variants defining serotype can be transmitted to children who received HBV vaccine. This observation justifies the systematic virological evaluation of 
children infected despite active immunization and their mother.

Publish with Bio Med Central and every scientist can read your work free of charge

"BioMed Central will be the most significant development for disseminating the results of biomedical research in our lifetime. " Sir Paul Nurse, Cancer Research UK

Your research papers will be:

- available free of charge to the entire biomedical community

- peer reviewed and published immediately upon acceptance

- cited in PubMed and archived on PubMed Central

- yours - you keep the copyright 